\title{
Methodology for leading indicators on sustainable regional development ${ }^{1}$
}

\author{
José Francisco de Carvalho Rezende \\ Universidade do Grande Rio (Unigranrio) / Programa de Pós-Graduação em Administração \\ Rio de Janeiro / RJ - Brazil \\ Maria Cristina Fogliatti de Sinay \\ Universidade do Grande Rio (Unigranrio) / Programa de Pós-Graduação em Administração \\ Rio de Janeiro / RJ - Brazil
}

\begin{abstract}
This research depicts an exploratory initiative focused on treating data to create score and rank indicators of sustainability that can be used to monitor sustainable regional development in metropolitan regions. In order to characterize, classify, and predict the conditions that might lead to the sustainable regional development of cities in a metropolitan area, the study of municipalities in the Baixada Fluminense (region neighboring the city of Rio de Janeiro) was adopted as a reference. The operational assumption for constructing and handling the variables took into account the existence of a legal framework, proposed by the government institute in charge of national research and socioeconomic data surveys, thereby establishing the parameters for the leading indicators required to characterize the conditions needed to achieve different development levels. Based on a series of secondary data, available in binary format for the year 2009 and obtained from the Brazilian Institute of Geography and Statistics (IBGE) Municipal Database (BDM), the statistical methods used in this paper indicated a high level of accuracy in the "mashing-up" constructs (Cronbach's Alpha equivalent to 0.824). They also showed the existence of different hierarchical clusters and functions able to classify the typology of municipalities based on selected leading indicators and $87.8 \%$ correspondence in the classification of observations. According to the purposes of this study, namely to discover a framework for measuring, discussing, and producing policies for sustainable development, some findings show that it is possible to create simple methods to deal with the complexity of sustainable regional development: the creation of types and hierarchies favors the development of policies focused on the comparison and alignment of local realities.
\end{abstract}

KEYWORDs: leading indicators; sustainable regional development; legal indicators framework; Baixada Fluminense; Metropolitan Region of Rio de Janeiro City.

DOI: http://dx.doi.org/10.1590/0034-7612134163

(c) (i)

Article submitted on 29 Apr. 2014 and accepted for publication on 4 Aug. 2015.

${ }^{1}$ The authors acknowledge the assistance provided by Faperj Carlos Chagas Foundation for Support of Research of the State of Rio de Janeiro, in view of the granted to purchase equipment and for installation of the Mais Baixada Laboratory in Unigranrio, Lapa campus, in the city of Rio de Janeiro. 


\section{Metodologia para indicadores antecedentes do desenvolvimento regional sustentável}

Este estudo retrata uma iniciativa exploratória focada no tratamento de dados, a fim de criar indicadores de sustentabilidade baseados em pontuações e hierarquias que podem ser usados para monitorar o desenvolvimento regional sustentável das regiões metropolitanas, utilizando como referência estudo abrangendo os municípios da Baixada Fluminense (RJ), para caracterizar, classificar e prever as condições regionais que antecederiam o desenvolvimento sustentável de cidades em uma mesorregião. O pressuposto operacional para a construção e manipulação das variáveis levou em consideração a existência de um marco legal, proposto pelo instituto governamental responsável pela coleta e análise de dados socioeconômicos nacionais - estabelecendo os parâmetros para os indicadores antecedentes necessários à caracterização do alcance de diferentes níveis de desenvolvimento. Com base em conjuntos de dados secundários, disponíveis em formato binário e obtidos do Instituto Brasileiro de Geografia Estatística (IBGE) - Base de Dados Municipal (BDM) —, a operacionalização de métodos estatísticos neste trabalho evidenciou o alto nível de precisão dos construtos (Alpha de Cronbach equivalente a 0,824), a existência de agrupamentos hierárquicos distintos e funções discriminantes para orientar a criação de uma taxonomia exploratória dos municípios com base em indicadores antecedentes selecionados e a correspondência de $87,8 \%$ na classificação das observações. De acordo com os propósitos do estudo - explorar um framework para mensurar, discutir e elaborar políticas de desenvolvimento sustentável —, os resultados apontam que é possível criar métodos simples para lidar com a complexidade do desenvolvimento regional sustentável: a criação de tipos e hierarquias favorece a formulação de políticas voltadas para a comparação e alinhamento das realidades locais.

Palavras-chave: indicadores antecedentes; desenvolvimento regional sustentável; marco legal de indicadores; Baixada Fluminense; Região Metropolitana do Rio de Janeiro.

\section{Metodología para los indicadores antecedentes de desarrollo regional sostenible}

Esta investigación representa una iniciativa de exploración enfocada en el tratamiento de los datos con el fin de crear indicadores de puntuación y de la fila que se pueden utilizar para supervisar el desarrollo regional sostenible de las regiones metropolitanas. Con el fin de caracterizar, clasificar y predecir las condiciones que conducen al desarrollo sostenible, fueron adoptados como referencia los municipios de la Baixada Fluminense - RJ. El supuesto operativo para la construcción y manipulación de las variables se tuvo en cuenta el marco legal, propuesto por el instituto gubernamental responsable de los parámetros de investigación y de datos socioeconómicos - para los indicadores adelantados requeridos para caracterizar las condiciones para alcanzar distintos niveles de desarrollo. Sobre la base de los conjuntos de datos secundarios y binarios para el año de 2009 obtenida del Instituto Brasileño de Geografía y Estadística (IBGE) — Base de Datos de Municipios (BDM) —, los métodos estadísticos utilizados en este trabajo indican el alto nivel de precisión de las construcciones "mashing-up" (Alpha de Cronbach equivalente a 0,824), la existencia de conglomerados jerárquicos y funciones distintas capaces de clasificar la tipología de municipios en base a indicadores adelantados seleccionados y 87,8\% correspondencia en la clasificación de las observaciones. De acuerdo con los propósitos del estudio - para explorar un marco para la medición, la discusión y elaboración de políticas — algunos resultados muestran que es posible crear métodos sencillos para hacer frente a la complejidad del desarrollo regional sostenible: la creación de tipos y jerarquías favorece la formulación de políticas centradas en la comparación y el balance de las realidades locales.

Palabras clave: indicadores antecedentes; desarrollo regional sostenible; marco legal de indicadores; Baixada Fluminense; Región Metropolitana de la ciudad de Río de Janeiro. 


\section{Introduction}

Sustainability is the outcome of a set of intelligent actions that can exert a positive influence on the agents' surroundings: from individual to society, from citizen to State, from worker to corporation, with new behaviors and values needed by them all, paving the way for consumption of resources while correcting the current biosphere degradation levels and rational use by subsequent generations (WCED, 1991; OECD, 1998; Buarque, 2002; Guivant, 2002; Barbieri, 2009; Veiga, 2008; World Bank, 2010).

In a scenario (Godet, 1993; Marcial and Grumbach, 2002) characterized by imbalance, actions focused on regional/local sustainable development must be systematized organically in order to achieve greater geographic reach, with better social reach and faster consequences (Araújo, 2010).

Along with these lines, conducting studies based on indiciary evidence (Ginzburg, 1989; Duarte, 1998; Richter and Pessolano, 2012) provides a reasonable alternative for early course corrections in government policies and management, resulting in less risky steering and more effective pursuit of local development at levels higher than those currently noted, above all in regions that have been affected by disorderly conurbation processes throughout their history.

More than a localized problem, there are numerous cases that highlight devastating effects of disorderly formation of metropolitan regions, when asymmetrical relationships emerge between the core metropolis and nearby towns whose economies become mere satellites of the hub (Boisier, 1995; Camargo, 2001; Rivero, 2002).

Addressing the need for a proactive approach to bridge current gaps in the sustainable development of municipalities within the Baixada Fluminense (Alves, 2003; Farias, 2005; Hasenclever and Faure, 2005, 2007), this study was produced by the "Mais Baixada" project $(\mathrm{SAM})^{2}$, hich is an institutional action undertaken by the Grande Rio University (Unigranrio) and supported by the Rio de Janeiro State Research Support Foundation (Faperj) ${ }^{3}$, creating and discussing a multidimensional overview of the leading indicators, in order to sound out conditions to achieve steadily rising sustainability levels.

The motivation and the main issue faced in this study is related to the difficulties of social actors in the search, organization, access, modeling, and interpretation of socio-economic data, especially in complex environments, such as those within metropolitan areas, where conurbation, the mix of social classes, and overt expectations in the social fabric generate needs that, although continued and urgent, often fail to take proper responses from policies and practices of public administration.

This study is grounded in a literature review focusing on the themes Sustainable Development, Local and Regional Development, Regional Sustainable Development Indicators; characterization of the region where this study will be applied (the Baixada Fluminense);

\footnotetext{
${ }^{2}$ Monitoring Methodology for Sustainability Indicators — "Sustainability Assessment Monitor".

3 "Carlos Chagas Filho" Rio de Janeiro State Research Support Foundation.
} 
presentation of the research methodological procedures; analysis; discussion through triangulation of objectives, references, and findings; and final remarks.

\section{Sustainable development}

Population growth is driven by advances in medicine and the development of science and technology over the second half of the $20^{\text {th }}$ century, which triggered a proportional upsurge in the need for natural resources.

The growth model at that time, which was purely economic, along with climate change that triggered the greenhouse effect and the growing hole in the ozone layer accentuated social inequalities while fostering disorderly urban growth and downgrading water quality. In addition to these aspects, the globalization phenomenon spread these impacts beyond national borders, prompting governments in many countries to put the model adopted so far into question, instead of taking steps to offset these negative effects (Roesch, Fischer and Mello, 2004; Scotto, Carvalho and Guimarães, 2007).

This situation went on until 1983, when the United Nations Organization (UN), concerned about the lack of knowledge on the relationship between environment and development, decided to create the World Commission on Environment and Development (WCED), asking it to prepare an exploratory study of this theme.

In 1997, the WCED published a report entitled Our Common Future, which introduced the phrase 'sustainable development,' defined as the ability to meet the current generation's needs without adversely affect the ability to serve future generations (WCED, 1991).

The recommendations in this study were reinforced during the UN Conference on Environment and Development, held in 1992 in Rio de Janeiro, better known as RIO-92. Among other important aspects, this event acknowledged the need to: (i) examine the environmental situation of the world as a whole; (ii) identify regional and global strategies to address major environmental issues; (iii) analyze strategies fostering sustainable development; and (iv) eliminate poverty in the developing countries.

Similarly to the rest of the world, Brazilian advances with regard to the relationships between human beings and the environment went through three phases (Ashley, 2002; Teixeira, 2006; Avena, 2011): the first, prior to the 1970s, was known as a time of alienation, characterized by the industrialization process, when merely palliative measures were introduced to offset the effects of this process, measures that were unable to prevent degradation.

Between 1970 and 1980, the passive environmental management phase emerged, when the way for the Brazilian environmental policy was paved.

The phase that emerged in the early 1990s, which extends to the current day, is the socalled pro-active environmental management phase.

This consisted of a time when rules, standards, and procedures were designed to adapt to new requirements related to the environment and its conservation, in parallel to the establishment of new government entities that have well-defined spheres of competence: the 
Environment Bureau under the Brazilian Presidency (Semam), the Brazilian Institute for the Environment and Renewable Natural Resources (Ibama), and the Brazilian Ministry of the Environment (MMA).

As a result of pressures posed by the Brazilian government, private companies, and organizations began to create response instruments of their own, also green seals, responsible operations, and environmental audits. This was also underpinned by rather detailed and broad-ranging organizational awareness of potential advantages provided by these and other tools (Fogliatti et al., 2011).

Even after the establishment of government entities and the promulgation of rules and standards, there was still a need to create tools for measuring the efficiency and effectiveness of actions implemented to preserve the environment and pave the way for sustainable development, tools known as environmental indicators (Ferreira, 2003), which are parameters of variables whose values represent the status of the associated environmental component, allowing the measurement of relative sustainability.

According to Costa (1999), from a tipping viewpoint, the sustainable development approach may indicate theoretical paradoxes that are hard to reconcile: (i) the trajectories of environmental analysis vis-a-vis urban analysis, as characterized in various fields of knowledge, but it melted into the view of sustainable development; and (ii) the theoretical constructs vis-a-vis intervention proposals, leading to estrangement between social critical analysis and urban planning.

Specifically with regard to this study, the intent is assessing development sustainability in the Baixada Fluminense. Thus, the indicators should represent, in a multifaceted way, social, cultural, economic, environmental, territorial, educational, technological, and political aspects, as well as access to basic services and resources.

\section{Regional/local development}

In order to iron out the regional inequalities that characterize Brazil (Roesch et al., 2004; Albuquerque, 2011) and spur inclusionary sustainable growth nationwide, grounded in the potential of these regions, the government drew up and implemented the Brazilian National Regional Development Policy (PNDR), between 2003 and 2008, under the aegis of the Brazilian Ministry of National Integration (MI).

Also, government entities providing support for the policy were introduced: the Regional Development Policy Bureau (SDR), the Regional Development Planning Department (DPDR) and the Regional Development Funds Management Department (DGFDR) (Brazil, 2011).

After several years of hard work, using data provided by the Brazilian Institute for Geography and Statistics (IBGE) for the 1990s, the PNDR classified the regions of Brazil into four different categories, through linking two variables together: (i) average household income, in the belief that this represents the relative wealth of the population; and (ii) per capita GDP growth, which represents the relative potential for economic growth. 
According to Santos (2002, 2005, 2006), regional development should be a responsibility of the government, but above all of the inhabitants of each region, who are more familiar with its specific characteristics and problems.

So, we come to the fore contemporary views on self-organization and self-integration of social actors to better match encouraging development by the State and legitimate local population's needs, streamlined by: (i) the economy and solidarity action (França Filho, 2008); (ii) the empowerment of local actors from a cultural perspective (Caetano, Silveira and Drumond, 2012); (iii) the adoption of consistent education and communication methodologies to gather participants in common and shared perspectives (Messeder and Herschmann, 2002).

In this study, we delimit regional/local development and the set of actions that underpin the promotion and appreciation of regional diversity, reconciling competitiveness and productive expression with social, cultural, and environmental values, striving to reduce unequal access to good-quality public services (Zapata et al., 2001; Vieira and Vieira, 2003; Sachs, 2004; Mello et al., 2006).

\section{Regional sustainable development indicators}

The steadily increasing output of studies in this field is notable, working with methodologies to monitor regional sustainable development indicators. If, on the one hand, the tradition of economic measurements should be relativized, driven by the need to develop supplementary metrics able to characterize the sources, flows, stages, and standards of sustainable development, on the other hand, the possibilities to measure and monitor aspects that are often intangible - such as well-being, for instance - are still not sufficiently provided with instruments to consolidate a final index that can reflect the concept of universal sustainable development in all its complexity, such as a Sustainability Footprint, for instance (Mansell e Weh, 1998).

Along with these lines, researchers have been exploring various mathematical analysis options in order to develop indicators, indexes, and constructs that simultaneously and rather sturdily express a three-part qualified performance: economic, social, and environmental (Balaton Group, 1999).

A significant trade-off in the development of indicators is related to causality and induction. More frequently, the attention given to formulate indicators focuses on consequences and outcomes, as a consequence, ex-post facto. In this case, we refer to the lagging indicators calculated after the action that gives rise to them, e.g. a final stage, type, or condition derived from intent or an ephemeral factor.

Another way of dealing with indicators is associated with the possibility of using them as behavioral predictors, signposting trends and outlooks, in addition to allowing corrective actions before a situation firms up. These are robust compound metrics that can characterize factors, steering variables that are known as leading indicators (Camba-Mendez et al., 1999; Etsy and Porter, 2002; Munda and Nardo, 2005). These indicators may be compared to the 
components of a vector: intensity, which, along with direction and application point, will lead to a new position and/or course shift.

In view of the complexity inherent to sustainability, the use of multi-criteria indicators and analyses (even without weighing) allows an interconnected action agenda to be drawn up, whose purpose is collective construction of new regional development levels, either through simple comparison and identification of gaps or sharing experiences and lessons learned by social players (World Economic Forum, 2002; Jha and Murthy, 2003).

The application of indicators for monitoring and sustainable development management undeniably gained momentum after the publication of the report Our Common Future by the UN in 1987, especially seeking for dependence and interdependence relationships between sustainability pillars - however, even after several studies, questions remain whether these pillars may be regarded as global imperatives or regional phenomena (Hosseini, 2012).

Based upon circumstantial evidence provided by exploratory studies, the definition of indicators to monitor sustainable development must be drawn up in detail, in order to characterize the measuring unit, the recommended frequency, the best place to survey, the equipment needed, and the procedures to be followed.

Hence, this is a systematic, standardized, task that needs a blend of search practices and the treatment of physical, social, and economic variables requiring care to generate trustworthy indicators in series that are open to generalization, if possible (Godet, 1986).

\section{The Baixada Fluminense Mesoregion}

The Baixada Fluminense Mesoregion, formerly known as the Baixada da Guanabara, consists mainly of areas framing the Guanabara Bay in Rio de Janeiro city (Figure 1). The urban creation dynamic of this area followed a partitioning rationale with neighboring municipalities, due mainly to the conditions introduced by the 1988 Brazilian Federal Constitution.

Since colonial times, the geographic characteristics of this region assigned it the role of a corridor for the agricultural production flow, with the original purpose of serving the interests of the Portuguese Court established in Rio de Janeiro city (Baía, 2006; Rodrigues, 2006; Silva, 2007).

Following the migratory rationale of 'seeking their fortune in the big city,' immigrant inflows from all over Brazil found the Baixada Fluminense convenient to access the Brazilian capital (it was Rio de Janeiro city before the 1960s), making their homes in irregular settlements that caused environmental degradation and resulted in the establishment of a violent parallel power ${ }^{4}$ to settle local disputes.

\footnotetext{
${ }^{4}$ The phrase 'transverse power' may reflect more accurately the intricate web of relationships between the official authorities and the parallel powers wielded by local drug lords and criminal militias.
} 
Figure 1

Baixada Fluminense: municipalities, formation, and foundation dates



Source: Baixada Cultural Forum - with adaptations.

Over time, this area grew into a cluster of dormitory towns, providing the hub Rio de Janeiro city with workforce, particularly less skilled workers, who play an important role, both from the social and the economic stand points, to the daily activities performed at the metropolis.

Still today, the 13 municipalities within the Baixada Fluminense - covering 2,806.6 square kilometers with a population close to 4 million inhabitants - are identified by their fragile public management regional sustainable development policies, practices and tools. The 13 municipalities are: Nova Iguaçu (NIG), São João de Meriti (SJM), Nilópolis (NIL), Belford Roxo (BRO), Queimados (QUE), Mesquita (MES), Seropédica (SER), Japeri (JAP), Paracambi (PAR), Itaguaí (ITG), Duque de Caxias (DCA), Magé (MAG), and Guapimirim (GPM).

News headlines, public opinion, and statistical records drawn up on the basis of field surveys outline profiles of dependence, violence, and abandonment for many of these sites, especially districts located further away from downtown (Farias, 2005; Baía, 2006).

This highlights the importance of actions structured on the basis of research methods, capacity building, and interventions in the Baixada Fluminense mesoregion, particularly 
when we take into account the investment and abilities that will be added to Rio de Janeiro city during the run-up prior to the milestone sports events scheduled for 2016.

There is a notable disparity between quality of life synthesis indicators (Table 1), when comparing the municipalities within the Baixada Fluminense to Rio de Janeiro city, which by polarizing the concentration of social and economic conditions in this region, magnifies the creation of inequality situations with little possibility to achieve sustainable development.

As a consequence it is quite reasonable to assume that absence of coordinated actions seeking and deploying resources to solve these structural problems in the Baixada Fluminense tends to worsen the imbalance between quality of life in this region and that experienced in the Rio de Janeiro state capital.

This issue may be synthesized through an analysis that identifies target towns for emergency upgrade actions, which points out "Japeri, Belford Roxo, São João de Meriti, and Nova Iguaçu as anti-images of sustainability and quality of life" (Farias, 2005).

\section{Table 1}

Overview of the Baixada Fluminense Municipalities - 2005

\begin{tabular}{|c|c|c|c|c|c|}
\hline & $\begin{array}{c}\text { Per capita } \\
\text { GDP } \\
\text { R\$ }\end{array}$ & $\begin{array}{l}\text { Per capita Budget } \\
\text { revenues } \mathrm{R} \$\end{array}$ & $\begin{array}{c}\text { Median income } \\
\text { of head of } \\
\text { household } R \$\end{array}$ & $\begin{array}{l}\text { Infant mortality } \\
\text { x } 1000 \text { births }\end{array}$ & $\begin{array}{l}\text { Average duration } \\
\text { of education } \\
\text { (years) of head of } \\
\text { household }\end{array}$ \\
\hline Belford Roxo (BRO) & $3,401.24$ & 283.01 & 350 & 23.59 & 5.5 \\
\hline Duque de Caxias (DCA) & $11,477.26$ & 623.94 & 361 & 16.59 & 5.8 \\
\hline Guapimirim (GPM) & $4,023.19$ & 831.17 & 302 & 15.82 & 4.9 \\
\hline Itaguaí (ITG) & 7,922.39 & 812.68 & 400 & 21.86 & 5.6 \\
\hline Japeri (JAP & $2,144.25$ & 399.22 & 300 & 22.08 & 4.7 \\
\hline Magé (MAG) & $3,346.83$ & 417.98 & 310 & 17.32 & 5.4 \\
\hline Mesquita (MES) & $3,453.42$ & 302.64 & 400 & 16.86 & 6.6 \\
\hline Nilópolis (NIL) & $4,213.58$ & 380.75 & 498 & 15.44 & 7.3 \\
\hline Nova Iguaçu (NIG) & $4,286.46$ & 285.56 & 377 & 22.50 & 6.0 \\
\hline Paracambi (PAR) & $3,602.12$ & 530.12 & 330 & 15.34 & 5.7 \\
\hline Queimados (QUE) & $5,061.20$ & 358.85 & 320 & 24.97 & 5.4 \\
\hline São João de Meriti (SJM) & $3,785.14$ & 296.59 & 400 & 21.07 & 6.2 \\
\hline Seropédica (SER) & $4,288.33$ & -- & 355 & 23.86 & 5.6 \\
\hline Rio de Janeiro & $28,405.00$ & $1,625.05$ & $1,354.31$ & 14.40 & 8.3 \\
\hline
\end{tabular}

Source: Farias (2005:43), with data added for Rio de Janeiro.

On the other hand, it is noticed that the preparation paving the way for major international events in Brazil — World Youth Day 2013, FIFA Confederations Cup 2013, FIFA World Cup 2014, Olympic Games 2016, Paralympic Games 2016 - requires revitalization of their host cities and their respective surrounding areas, having as the mainspring practices focused 
on social and environmental outcomes, anchored on the adoption of sustainable regional development mechanisms whose main sustainability orchestration agents are public authorities that pursue ongoing improvements.

\section{Methodological procedures}

The use of quantitative methods to describe a specific situation leads us to understand the extent to which assorted observations are similar or differ, either by comparing metrics or preparing more complex constructs through combination of variables. Furthermore, they allow hypotheses to be tested that underpin conjectures on characteristics of the variables and elements in a sample.

The research issue currently under analysis is related to the possibility of characterizing, typifying, and predicting conditions that precede regional sustainable development of towns in the same metropolitan region.

Therefore this is an exploratory theoretical modeling study that attempts to characterize indicators, constructs, and a baseline methodological approach to interconnect them.

The use of mash-up development indexes and indicators - study guideline - is portrayed by Ravallion (2010) in a report submitted to the World Bank. Ravallion (2010) concluded there is a need to observe procedures that assess the robustness of constructs that are created, while the critical use thereof must be sparse, for specific purposes far more than for comparative analyses between a group of observations rather than for explaining the observation position in a hierarchy.

Still from the indicator construction methodology standpoint, Munda and Nardo (2005) notice the use of compound indicators has becoming increasingly common to describe policy-making situations, both macro-economic and in other fields of public interest. The proliferation of this technique should be accompanied by greater strictness in the use of mathematical rules and the meaning between what is shown for explanation, and what can be explained, in fact, through the use of weighing agents, limited to an extensive literature review that can express social options within an observed reality — whereby little ambition and much ambition might be more than recommendable.

This study was conducted by using secondary data obtained from regular surveys (1999, 2001, 2002, 2004 to 2006, 2008, 2009, 2011), conducted by the IBGE, entitled Brazilian Municipalities Profile, handling the collection year 2009. ${ }^{5}$ Most of these data is available in binary format, in order to characterize the existence, or not, of policies, practices, procedures, facilities, equipment, etc., which characterize a legal framework for regional development.

${ }^{5}$ Site: <www.ibge.gov.br/home/estatistica/economia/perfilmunic/2009/default.shtm>. Accessed on: August 27, 2012. 
This survey by the IBGE portrays the existence and/or nature of public management policies, equipment, and practices in Brazilian municipalities, conducted on a census basis, with a total of 5,565 observations, basically qualitative and informative, playing a role that arise from the new arrangements of the State and complying with the goals of supporting and overseeing local authority management policies and acts.

Data collected by the IBGE encompass 738 variables that cover the following dimensions/constructs on the structure of the State apparatus and municipal management: (i) information on mayors; (ii) personnel employed under the Brazilian labor law in the direct and indirect civil service; (iii) municipal planning, legislation and tools; (iv) municipal management resources and funds; (v) information and communication technology; (vi) education policy; (vii) culture policy; (viii) sports policy; (ix) housing policy; (x) transportation policy; (xi) healthcare policy; (xii) safety and access to justice policy; (xiii) human rights policy; (xiv) gender management policy; (xv) environment policy; and (xvi) social welfare policy.

After downloading the file, the qualitative data for 2009 were entered to a binary standard, and then entered to the software SPSS, version 15.0, in order to perform univariate, bivariate, and multivariate analyses (Everitt, 1974, 1991; Hair et al., 1998).

Among the dimensions addressed by the IBGE (Appendix 1), the following were selected to make up an exploratory panel of leading indicators: (i) Municipal Planning, Legislation and Tools; (ii) Municipal Planning Resources and Funds, Information and Communication Technology (ICT); (iii) Education, Culture, and Sports Policy; (iv) Housing and Transportation Policy; (v) Healthcare and Social Welfare Policy; (vi) Safety and Access to Justice Policy; (vii) Human Rights Policy; (viii) Environment Policy.

The selection of variables observed the guidelines of multiple dimensions contained in the Global Reporting Initiative (GRI) framework, depicting, e.g. social dimension based on indicators for health and social care, safety and access to justice, and human rights. The focus of this study is normative and it discusses the applicability of the variables already available in official data banks to support retrospective and prospective discussions on sustainable regional development.

According to Singh and partners (2012), indicators and frameworks to increase data on sustainability should comply with the prior application of bivariate and multivariate analysis to test the actual influence of the indicator or variable on the policy that aims to track, observing minimum methodological requirements to obtain consistency of composite indices. The predominance of multivariate and multilevel pair methodological approaches to sustainable development indicators might make it easier to understand the models' scheme: (i) hierarchical structure of the GRI; (ii) theme indicator of the UN Commission for Sustainable Development (UNCSD); (iii) sustainability metrics of the Institute of Chemical Engineers (IChemE); (iv) sustainable development indicator Wuppertal; and (v) Holistic framework for sustainability assessment.

As secondary data were turned into the binary standard, indicators were created in order to express the eight constructs, calculated by the sum of the values of binary variables constituting each dimension in this survey. 


\section{Results and analysis}

The operational definition of constructs observed the aggregation pattern of Appendix 1, providing, by means of indicators ranging from 0 to 10 - obtained having the sum of original variables as a basis - greater variability in the issues noticed in the set of municipalities in the database, improving the analysis and interpretation.

For the purposes of this exploratory study, the aggregation of existing dimensions in the study by the IBGE (2009) was obtained - still without a rather accurate view of the correlations between variables: (i) Education, Culture, and Sports; (ii) Housing and Transportation; (v) Healthcare and Social Welfare; (vi) Safety and Access to Justice; (vii) Human Rights and Diversity (tests and reliability level in Table 2).

Table 2

\section{Confidence test for the exploratory constructs}

\begin{tabular}{|lcccc|}
\hline Construct & Number of items & Cronbach's Alpha & Consistency & OK \\
Municipal Planning & 10 & 0.810 & Good & NOK \\
Local Management and ICT & 10 & 0.549 & Poor & NOK \\
Education, culture and sport & 10 & 0.398 & Insufficient & OK \\
Housing and transportation & 10 & 0.661 & Poor & NOK \\
Healthcare and social welfare & 10 & 0.535 & Tolerable & OK \\
Safety and access to justice & 10 & 0.623 & Poor & NOK \\
Human rights and diversity & 10 & 0.435 & Tolerable & OK \\
Environment & 10 & 0.638 & Good & OK \\
Leading Indicator for Sustainability & 8 & 0.824 & & \\
\hline
\end{tabular}

Source: Prepared by the authors.

Tables 3 and 4 display non-parametric tests of differences in construct averages - Mann-Whitney U test - based on the universe of Brazilian municipalities, with extraction for the Rio de Janeiro state and a specific non-random sample consisting of the thirteen municipalities within the Baixada Fluminense. 
Table 3

Descriptive statistics of the constructs: comparison of the population of Brazil and the Baixada Fluminense Sample

\begin{tabular}{|lcccccccccc|}
\hline \multicolumn{1}{c}{ Constructs } & \multicolumn{3}{c}{ Population - Brazil } & \multicolumn{3}{c}{ Sample - Baixada } & \multicolumn{2}{c|}{ U Test } \\
\cline { 2 - 9 } & $\mathrm{N}$ & $\mathrm{m}$ & $\mathrm{d}$ & $\mathrm{n}$ & $\mathrm{X}$ & $\mathrm{S}$ & $\mathrm{BF}$ & Sig. & $\mathrm{H}_{0}$ \\
\hline Municipal Planning & 5,552 & 3.78 & 2.80 & 13 & 7.92 & 1.26 & $>$ BR & 0.000 & OK \\
Local Management and ICT & 5,552 & 6.77 & 1.63 & 13 & 7.31 & 1.44 & $>$ BR & 0.178 & NOK \\
Education, culture and sport & 5,552 & 4.04 & 1.62 & 13 & 4.54 & 1.33 & $>$ BR & 0.196 & NOK \\
Housing and transportation & 5,552 & 3.76 & 2.00 & 13 & 6.85 & 1.21 & $>$ BR & 0.000 & OK \\
Healthcare and social welfare & 5,552 & 6.75 & 1.63 & 13 & 8.15 & 1.07 & $>$ BR & 0.001 & OK \\
Safety and access to justice & 5,552 & 2.53 & 1.69 & 13 & 5.39 & 1.66 & $>$ BR & 0.000 & OK \\
Human rights and diversity & 5,552 & 3.26 & 1.29 & 13 & 4.69 & 1.55 & $>$ BR & 0.000 & OK \\
Environment & 5,552 & 2.79 & 1.95 & 13 & 5.46 & 1.85 & $>$ BR & 0.000 & OK \\
General leading indicator & 5,552 & 4.19 & 1.24 & 13 & 5.95 & 1.02 & $>$ BR & 0.000 & OK \\
\hline
\end{tabular}

Source: Prepared by the authors.

The underlying hypothesis for all constructs is that these municipalities have the best leading indicators for sustainability in terms of other municipalities in Brazil as a whole, as well as when compared to others in the Rio de Janeiro state.

Table 4

Descriptive statistics of the constructs: comparison of RJ extraction RJ and the Baixada Fluminense sample

\begin{tabular}{|c|c|c|c|c|c|c|c|c|c|}
\hline \multirow[t]{2}{*}{ Constructs } & \multicolumn{3}{|c|}{ Extraction - Rio de Janeiro } & \multicolumn{3}{|c|}{ Sample - Baixada } & \multicolumn{3}{|c|}{ U Test } \\
\hline & $\mathrm{N}$ & $\mathrm{m}$ & $d$ & $\mathrm{n}$ & $x$ & $S$ & $\mathrm{BF}$ & Sig. & $\mathrm{H}_{0}$ \\
\hline Municipal Planning & 79 & 6.98 & 2.59 & 13 & 7.92 & 1.26 & $>\mathrm{RJ}$ & 0.517 & NOK \\
\hline Local Management and ICT & 79 & 7.81 & 1.30 & 13 & 7.31 & 1.44 & $<\mathrm{RJ}$ & 0.223 & NOK \\
\hline Education, culture and sport & 79 & 5.10 & 1.31 & 13 & 4.54 & 1.33 & $<\mathrm{RJ}$ & 0.177 & NOK \\
\hline Housing and transportation & 79 & 5.51 & 1.69 & 13 & 6.85 & 1.21 & $>\mathrm{RJ}$ & 0.006 & OK \\
\hline Healthcare and social welfare & 79 & 8.00 & 1.12 & 13 & 8.15 & 1.07 & $>\mathrm{RJ}$ & 0.641 & NOK \\
\hline Safety and access to justice & 79 & 4.65 & 1.88 & 13 & 5.39 & 1.66 & $>\mathrm{RJ}$ & 0.131 & NOK \\
\hline Human rights and diversity & 79 & 4.46 & 1.58 & 13 & 4.69 & 1.55 & $>\mathrm{RJ}$ & 0.468 & NOK \\
\hline Environment. & 79 & 5.11 & 1.78 & 13 & 5.46 & 1.85 & $>\mathrm{RJ}$ & 0.576 & NOK \\
\hline General leading indicator & 79 & 5.90 & 1.05 & 13 & 5.95 & 1.02 & $>$ RJ & 0.302 & NOK \\
\hline
\end{tabular}

Source: Prepared by the authors. 
Table 5 displays the individual scores of the municipalities in the Baixada Fluminense mesoregion for each of the dimensions covered by the IBGE survey.

Table 5

Absolute scores of the constructs for the municipalities in the Baixada Fluminense

\begin{tabular}{|c|c|c|c|c|c|c|c|c|c|c|c|c|c|}
\hline Constructs $\backslash$ Municipalities & NIG & PAR & NIL & MES & DCA & BRO & SER & ITG & SJM & JAP & QUE & GPM & MAG \\
\hline Municipal Planning & 8 & 9 & 10 & 9 & 7 & 7 & 8 & 7 & 10 & 7 & 7 & 8 & 6 \\
\hline Local Management and ICT & 7 & 10 & 7 & 8 & 8 & 7 & 9 & 8 & 6 & 7 & 7 & 7 & 4 \\
\hline Education, culture and sport & 7 & 5 & 6 & 4 & 6 & 5 & 4 & 4 & 5 & 3 & 4 & 2 & 4 \\
\hline Housing and transportation & 7 & 9 & 6 & 8 & 6 & 7 & 7 & 7 & 6 & 8 & 7 & 4 & 7 \\
\hline Health. and social welfare & 10 & 9 & 8 & 8 & 9 & 9 & 8 & 8 & 8 & 9 & 6 & 7 & 7 \\
\hline Safety and access to justice & 7 & 6 & 6 & 4 & 9 & 5 & 6 & 6 & 6 & 3 & 4 & 3 & 5 \\
\hline Human rights and diversity & 7 & 5 & 6 & 6 & 1 & 5 & 3 & 4 & 4 & 5 & 6 & 4 & 5 \\
\hline Environment & 9 & 5 & 6 & 7 & 7 & 5 & 5 & 5 & 6 & 2 & 4 & 7 & 3 \\
\hline
\end{tabular}

Source: Prepared by the authors.

In order to characterize a hierarchy of municipalities based on the leading indicators for sustainability metrics, the scores of these municipalities were turned into ranks with subsequent calculation of the average rank for each observation taken at the time as the corresponding leading indicator for the sustainability of each municipality in the Baixada Fluminense (Table 6).

Table 6

Ranks for municipalities in the Baixada Fluminense by scores in the study constructs

\begin{tabular}{|c|c|c|c|c|c|c|c|c|c|c|c|c|c|}
\hline Construct $\backslash$ Municipalities & NIG & PAR & NIL & MES & DCA & BRO & SER & ITG & SJM & JAP & QUE & GPM & MAG \\
\hline Municipal Planning & 5 & 3 & 1 & 3 & 8 & 8 & 5 & 8 & 1 & 8 & 8 & 5 & 13 \\
\hline Local Management and ICT & 6 & 1 & 6 & 3 & 3 & 6 & 2 & 3 & 12 & 6 & 6 & 6 & 13 \\
\hline Education, culture and sport & 1 & 4 & 2 & 7 & 2 & 4 & 7 & 7 & 4 & 12 & 7 & 13 & 7 \\
\hline Housing and transportation & 4 & 1 & 10 & 2 & 10 & 4 & 4 & 4 & 10 & 2 & 4 & 13 & 4 \\
\hline Health. and social welfare & 1 & 2 & 6 & 6 & 2 & 2 & 6 & 6 & 6 & 2 & 13 & 11 & 11 \\
\hline Safety and access to justice & 2 & 3 & 3 & 10 & 1 & 8 & 3 & 3 & 3 & 12 & 10 & 12 & 8 \\
\hline Human rights and diversity & 1 & 5 & 2 & 2 & 13 & 5 & 12 & 9 & 9 & 5 & 2 & 9 & 5 \\
\hline \multirow[t]{2}{*}{ Environment. } & 1 & 7 & 5 & 2 & 2 & 7 & 7 & 7 & 5 & 13 & 11 & 2 & 12 \\
\hline & 2.63 & 3.25 & 4.38 & 4.38 & 5.13 & 5.5 & 5.75 & 5.88 & 6.25 & 7.5 & 7.63 & 8.88 & 9.13 \\
\hline
\end{tabular}

Source: Prepared by the authors. 
After the univariate treatment, the observations of the 5,565 Brazilian municipalities were run through a hierarchical clustering process by means of the SPSS procedures, based on the Ward method and using the squared Euclidean distance as an interval measurement, in order to assess the existence of various types of municipalities in terms of the leading standards for sustainable development.

The Ward method is intended to form clusters by comparing pairs of observations and calculating the respective distances from the average variables in each cluster, through iterations that end when the lowest possible variations are obtained for the sum of the squared deviations (SQD) and all observations are clustered (Hair et al., 1998).

Table 7 displays the test results for clusters, characterizing differences in variance in the three clusters for all variables per se (Anova) and, from the standpoint of the joint effect of all variables, the leading indicators for sustainability (Manova).

Table 7

Variance equality test for the constructs in the hierarchical clusters

\begin{tabular}{|lccc|}
\hline Construct & Wilks' Lambda & F & Significance \\
\hline Municipal Planning (PLA) & 0.44 & $3,475.69$ & 0.000 \\
Local Management and ICT (MAN) & 0.68 & $1,302.61$ & 0.000 \\
Education, culture and sport (ECS) & 0.70 & $1,173.99$ & 0.000 \\
Housing and transportation (H\&T) & 0.57 & $2,079.61$ & 0.000 \\
Healthcare and social welfare (H\&W) & 0.75 & 922.10 & 0.000 \\
Safety and access to justice (S\&J) & 0.58 & $1,991.48$ & 0.000 \\
Human rights and diversity(HRD) & 0.90 & 304.38 & 0.000 \\
Environment (ENV) & 0.62 & $1,740.72$ & 0.000 \\
& & & 0.000 \\
\hline
\end{tabular}

Source: Prepared by the authors.

In order to endow the exploratory study with some predictive power, discriminating functions were calculated, supported by the SPSS, able to represent classification rules for observations based on the hierarchical groupings identified on the basis of the construct adopted as dimensions to the leading indicators for sustainability. Table 8 reproduces the structure and weight of each construct for the purpose of making the classification rules, which were respectively names as Infrastructure Management (Fx) and Civil Rights (Fy). 
Table 8

Structural variables matrix for classification functions

\begin{tabular}{|lcc|}
\hline & \multicolumn{2}{c|}{ Function } \\
\cline { 2 - 3 } Construct & $\begin{array}{c}\text { Infrastructure } \\
\text { Management (IM) }\end{array}$ & Civil Rights (CR) \\
\hline Municipal Planning (PLA) & 0.611 & -0.481 \\
Housing and transportation (H\&T) & 0.473 & 0.335 \\
Environment (ENV) & 0.436 & -0.145 \\
Local Management and ICT (MAN) & 0.377 & -0.076 \\
Education, culture and sport (ECS) & 0.356 & 0.235 \\
Healthcare and social welfare (H\&W) & 0.318 & -0.044 \\
Safety and access to justice (S\&) & 0.455 & 0.576 \\
Human rights and diversity (HRD) & 0.169 & 0.381 \\
\hline
\end{tabular}

Source: Prepared by the authors.

Table 9 portrays the accuracy test for the classification functions, measuring the ability to discriminate observations in the groups, significant when $\mathrm{p}<0.00$.

Table 9

Eigenvalues and significance tests for the classification functions

\begin{tabular}{|lccccc|}
\hline Function & Eigenvalue & $\begin{array}{c}\text { Explained } \\
\text { Variance }\end{array}$ & $\begin{array}{c}\text { Canonical } \\
\text { Correlation }\end{array}$ & Wilks' Lambda & Significance \\
\hline Infrastructure Management (IM) & 3.284 & $96.9 \%$ & 0.88 & 0.211 & 0.000 \\
Civil Rights (CR) & 0.104 & $3.1 \%$ & 0.31 & 0.905 & 0.000 \\
\hline
\end{tabular}

Source: Prepared by the authors.

Reducing the 8 dimensions to only 2 classification rules, a graphic presentation was prepared, showing the scatter pattern of observations taken in 5,565 Brazilian municipalities, for the 2 axes obtained, noticing the predominance of the Infrastructure Management function as the classification rule with the greatest power of separation in the clusters (Figure 2), as shown in the explained variance for the universe under study (96.9\%):

จ Group 1: "Instrumentalized": consists of towns with higher levels of apparent infrastructure and mechanisms to achieve sustainable local development, in addition to be focused on guaranteeing Civil Rights.

- Group 2: "Reactive": encompasses municipalities where the apparatus underpinning the Rule of Law is less developed.

- Group 3: "Disintegrated": observations indicate less infrastructure and poorer access to sustainability management mechanisms. 
Figure 2

Distribution of observations based on the classification functions

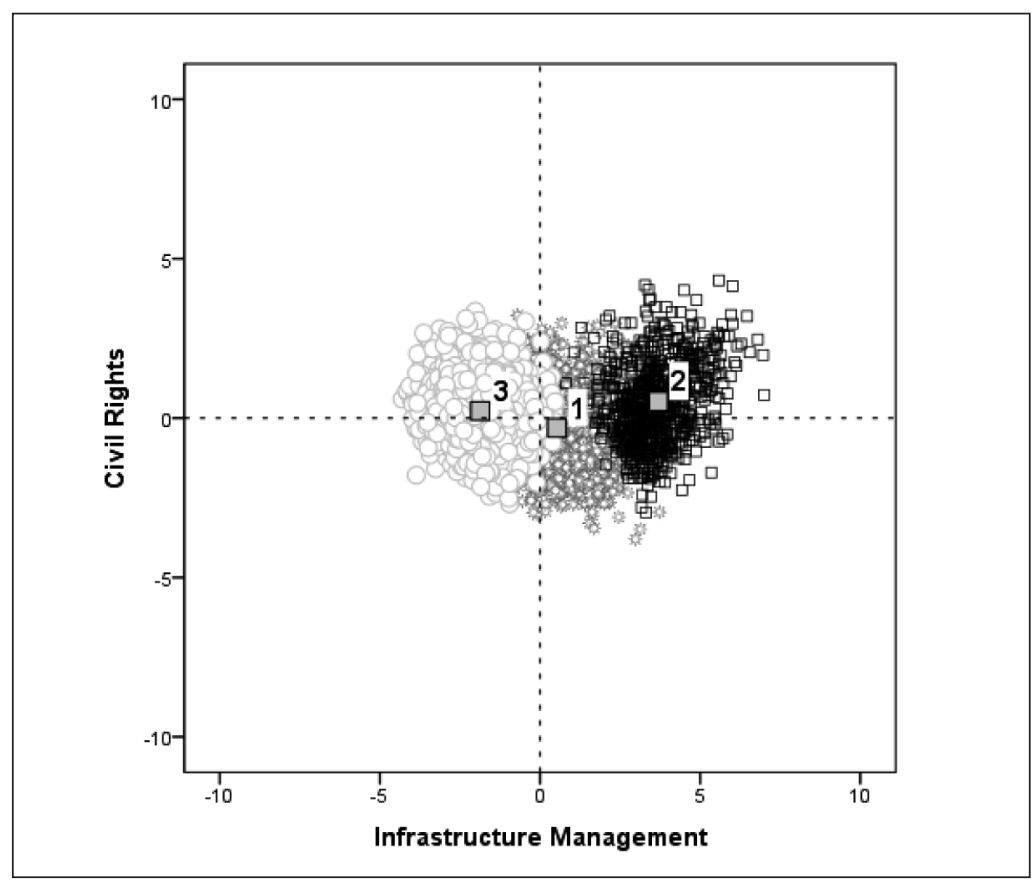

Source: Prepared by the authors.

Table 10 displays a comparison between the observations grouped by the hierarchical analysis procedure and the classification provided by the discriminating functions, obtaining a correspondence of $87.8 \%$ correctly grouped and classified.

Table 10

Distribution of the cases observed by cluster and classification rules

\begin{tabular}{|c|c|c|c|c|c|c|}
\hline & & \multirow[b]{2}{*}{ Ward Method } & \multicolumn{3}{|c|}{ Cluster Forecast } & \multirow[b]{2}{*}{ Total } \\
\hline & & & 1 & 2 & 3 & \\
\hline \multirow{6}{*}{ Original } & \multirow{3}{*}{ Count } & 1 & 1840 & 187 & 248 & 2275 \\
\hline & & 2 & 41 & 583 & 0 & 624 \\
\hline & & 3 & 205 & 0 & 2461 & 2666 \\
\hline & \multirow{3}{*}{$\%$} & 1 & 80.9 & 8.2 & 10.9 & 100.0 \\
\hline & & 2 & 6.6 & 93.4 & .0 & 100.0 \\
\hline & & 3 & 7.7 & 0.0 & 92.3 & 100.0 \\
\hline
\end{tabular}

Source: Prepared by the authors. 
Since this study is intended to explore the metrics for leading/lagging sustainable development conditions in the Baixada Fluminense, the observations were widely distributed, as reflected in the scatter pattern, in terms of the classification functions, with this appearing only for the municipalities in the Rio de Janeiro state, with presentation on panels that represent the towns located in and out of the Baixada Fluminense (Table 11 and Figure 3).

Table 11

Classification of municipalities in the Baixada Fluminense by leading indicators for sustainability

\begin{tabular}{|c|c|c|c|c|}
\hline Centroid & Function 1 & Function 2 & Cluster & $\begin{array}{l}\text { Municipalities in the Baixada Fluminense - } \\
\text { Rio de Janeiro State }\end{array}$ \\
\hline 1 & 0.855 & -0.357 & Reactive & Japeri, Queimados, Guapimirim, Magé \\
\hline 2 & 3.889 & 0.588 & Instrumentalized & $\begin{array}{l}\text { Nova Iguaçu, Paracambi, Nilópolis, Mesquita, } \\
\text { Duque de Caxias, Belford Roxo, Seropédica, Itaguaí, } \\
\text { São João de Meriti }\end{array}$ \\
\hline 3 & -1.640 & 0.167 & Disintegrated & - \\
\hline
\end{tabular}

Source: Prepared by the authors.

Finally, in order to assess the capacity of this analysis model to serve as a metric benchmarking mechanism underpinning discussions on sustainability and regional development, the findings were reproduced for the City of Rio de Janeiro, due to its status as an agent in center-periphery relationships in this region (Table 12).

Table 12

Construct scores for leading indicators for sustainability in the Rio de Janeiro municipality

\begin{tabular}{|lcccccccc|c|}
\hline & PLA & MAN & ECS & H\&T & H\&W & S\&J & HRD & ENV \\
\hline Rio de Janeiro & 10 & 9 & 6 & 7 & 9 & 9 & 5 & 6 \\
\hline
\end{tabular}

Source: Prepared by the authors.

Based on the indicators for the City of Rio de Janeiro, the Euclidean distances were calculated, taking into account the measurements of the eight dimensions of the leading indicators for sustainability for each municipality in the Baixada Fluminense, shown in Table 6, which also presents the rank for each town, and the relative position arising from changes in these ranks (Table 13). 
Table 13

Euclidean distance to the benchmark in $\mathrm{R}^{8}$ for the constructs of leading indicators for sustainability

\begin{tabular}{|c|c|c|c|c|c|c|c|c|c|c|c|c|c|}
\hline & NIL & PAR & SJM & SER & ITG & NIG & DCA & BRO & MES & QUE & MAG & JAP & GPM \\
\hline Multivariate distance & 4 & 4.12 & 4.69 & 4.80 & 5.10 & 5.20 & 5.29 & 5.57 & 5.92 & 7.48 & 8.60 & 8.66 & 8.66 \\
\hline Multivariate rank & 1 & 2 & 3 & 4 & 5 & 6 & 7 & 8 & 9 & 10 & 11 & 12 & 12 \\
\hline Univariate position rank & 3 & 2 & 9 & 7 & 8 & 1 & 5 & 6 & 4 & 11 & 12 & 10 & 13 \\
\hline Variation rank & +2 & 0 & +6 & +3 & +3 & -5 & -2 & -2 & -5 & +1 & +2 & -2 & -1 \\
\hline
\end{tabular}

Source: Prepared by the authors.

\section{Discussion}

From the definition, processing and analyses of the constructs arising from the data released by the IBGE, it was possible to characterize indicators and constructs constituting leading indicators for sustainability in the Baixada Fluminense.

Even with a low reliability level, inclusion of the Education, Culture and Sports construct did not result in any drop in the quality of the findings. To the contrary, the weak correlation ascertained among the variables giving rise to this construct could well prompt discussions over the absence of a systematic approach focused on initiatives pursuing integrated citizen formation and training in general, which is a competence assigned to Brazilian municipalities.

For all the constructs established in this study as leading indicators for sustainable development, municipalities located in the Baixada Fluminense proved more effective than other Brazilian municipalities, in terms of policies and equipment. It was only for Local Management and Information of Communications Technologies and Education, Culture, and Sports - regarded as attributes of citizen formation - that it was not possible to identify differences in standards for any statistical significance: for Management, with a minor positive difference compared to the simple central point of scale; and for Education, a slightly negative gap compared to the midpoint.

When compared only with other towns in the Rio de Janeiro state, although outperforming them in six of the dimensions studied, an average difference was found for the set of municipalities in the Baixada Fluminense, statistically significant when $\mathrm{p}<0.01$, only for the Housing and Transportation construct.

Among the eighty variables studied herein, these were identified as existing in all municipalities in the Baixada Fluminense (construct in parentheses): (i) Zoning Laws or Equivalent (PLA); (ii) Works Code (PLA); (iii) Behavior Code (PLA); (iv) Master Plan (PLA); (v) Real Estate Registry (MAN); (vi) IS Service Tax Registry Database (MAN); (vii) Town Hall Computer Network (MAN); (viii) Town Hall Computers with Internet Access (MAN); (ix) Municipal Education Council (ECS); (x) Registry or Survey of Families Interested in Housing Programs (H\&T); (xi) Collective Transportation by Intra-Municipal Buses (H\&T); (xii) Collective Transportation by Inter-Municipal Buses (H\&T); (xiii) Emergency Unit (H\&W); (xiv) Family Health Program (H\&W); and (xv) Child Protection Council (HRD). 
Figure 3

Observation panel for Rio de Janeiro state based on the classification functions



Source: Prepared by the authors. 
As a counterpart, the less frequent variables (construct and occurrence percentage shown in parenthesis), were: (i) Vocational Training Courses (ECS - 0.00); (ii) Municipal Transportation Council (H\&T - 0.00); (iii) Environmental Protection Stations (ENV - 0.00); (iv) Municipal Policy Plan For Women (HRD - 0.00); (v) Youth and Adult Education Projects (ECS - 0.08); (vi) Detention Home for Adolescents in Conflict with the Law (HRD - 0.08); (vii) Municipal Housing Plan (H\&T - 0.15); (viii) Medical Examiner's Office (S\&J) - 0.15); (ix) Policy, Program or Action for the Resocialization of Former Prisoners (HRD) - 0.15); (x) Environmental Agreements between Local and State Authorities (ENV - 0.15); (xi) Environmental Agreements between Local and Federal Authorities (ENV - 0.15); (xii) Municipal Sports Council (ECS - 0.23); (xiii) Specialized Dispute Settlement Unit (S\&J - 0.23); (xiv) Policy or Actions against Forced Labor (HRD - 0.23); and (xv) Policy, Program, or Actions for Homeless (HRD - 0.23).

The operationalization method for the variables allowed the classification of the entire population of Brazilian municipalities at an accurate trustworthiness level, with relative convergence between the demarcation of municipalities in the Baixada Fluminense in the univariate and multivariate analyses.

In other words, for the cases under study, the creation of scores through the addition of binary variables is a simple alternative to prepare rather sophisticated statistical constructs, although it is worth noticing the calculation of hierarchical clusters had evidence for the "Reactive" set of municipalities — Guapimirim, Magé, Japeri, and Queimados — lagging behind their more advanced counterparts from the sustainable development viewpoint, while at the same time this does not indicate the existence of municipalities in the Baixada Fluminense within the "Disintegrated" group, seemingly lacking sustainable development policies and equipment.

In addition to being the least developed group in the Baixada Fluminense, the "Reactive" towns are also the furthest away from the Rio de Janeiro benchmark.

Using graphs to characterize the scatter patterns of discriminating scores around the cluster core, it was possible to identify a leading indicator for the sustainability boundary in the Rio de Janeiro state. It is worth stating that, although this is not the case of towns within the Baixada Fluminense, 5 cases were identified out of the 92 municipalities in the Rio de Janeiro state in the "Disintegrated" cluster: Comendador Levy Gasparian, São José de Ubá, Sumidouro, Trajano de Morais, and Varre-Sai.

The construct dimensions that are more directly associated with the classification power of discriminating functions (Table 10) confirm the importance of Municipal Planning Actions to establish a situation of rather harmonious sustainable development.

Regarding the statement by Farias (2005) that "anti-images of sustainability and the quality of life," in this project we see a better charted framework through indicators and constructs built up by using univariate and multivariate processes - and, as in 2005, the municipality of Japeri still remains among the town within the Baixada Fluminense mesoregion having the lowest scores in the leading indicators for sustainable development.

From the standpoint of the PNDR and assuming a bivariate approach to chart observations - growth in per capita income and mean values of family income - municipalities in 
the Baixada Fluminense were classified as either Dynamic or Stagnant, but without a clear definition on the cut-off point in a situation fairly remote from a possible future benchmark based on Rio de Janeiro city.

It is worth noticing that, from the multivariate standpoint, the municipality with the highest leading indicator — and, as a consequence, the greatest potential - is the town of Nilópolis, which has not faced the problems of size or rising population density that have been faced by Duque de Caxias and Nova Iguaçu and Belford Roxo and São João de Meriti, respectively.

The findings obtained by working with leading indicators is seemingly coherent with the historical background of municipalities in the Baixada Fluminense, classifying the towns of Japeri, Queimados, Guapimirim, and Magé as sites with fewer variables linked to the characterization of the Rule of Law: Public Safety and Access to Justice.

The calculation of scores and ranks through two approaches has led to findings that clash to some extent, i.e. attention must be paid to the possibility that selecting a benchmark - such as in the case of Rio de Janeiro city - always characterizes choices and a mental model, which affect ranking. However, when focusing on the four towns (around 1/3 of the observations), lower leading indicators for sustainable development are scored, the group remains unchanged, and only their ranking order varies. It may be reasonable to claim that the two approaches used highlight critical aspects in very similar ways, although having no equivalent accuracy for the more effective towns.

A last point to be addressed concerns the univariate score for the leading indicator for sustainability found in Duque de Caxias in the Human Rights and Diversity construct, which is the lowest among all municipalities in this study, bringing this town down from the $5^{\text {th }}$ to the $7^{\text {th }}$ position in the Baixada Fluminense mesoregion, when adopting the multivariate indicator.

Although Duque de Caxias is the largest city, with the highest per capita income and the greatest municipal budget, the survey conducted by the IBGE in 2009 did not register the existence of: (i) municipal plan for a policy on women; (ii) reference center for battered women; (iii) tool receive denounces of non-compliance with human rights; (iv) policy or actions fighting against forced labor; (v) policy, program, or actions for homeless people; (vi) policy, program, or actions to resocialize former prisoners; (vii) policy or program for the elderly; (viii) policy for children and adolescents; (ix) prison center for adolescents in conflict with the law. These findings allow confirming the evidence of the lack of sustainable development conditions in the city.

\section{Final remarks}

This study allows outlining methodological alternatives to understand and interpret sustainable development in Brazilian municipalities. As an exploratory study, it is necessarily subject to confirmation and validation, through new data extraction and sampling or comparison to other approaches for operationalizing variables. 
The main contribution of this study is related to the preparation of leading indicators and the method to characterize stages and potentialities for regional sustainable development of a sample of municipalities.

We believe that, for the purpose of sustainable management of regional development, the adoption of leading indicators is a reasonable and cost effective alternative. Moreover, a processing by means of spreadsheets may create a panorama of information with potential for interaction and understanding by public servants as a whole.

Complementing the focus on "pillars" of sustainable development brought by the UNCSD and GRI models, the idea behind leading indicators is related to the "foundations": as a social plus technical building process, without stability of the "foundations," the "pillars" might not be safe even against small shocks.

The findings indicate a multi-dimensional curve for the supply of sustainability policies and actions for the Brazilian municipalities, based on eighty variables organized into eight constructs and operationalized so that it produces classification functions to group observations.

For theoretical purposes, the implications lie on the possibility to create types and stages for the maturity of public administration, leading to a better understanding of sustainable development through the application of univariate and multivariate scores, e.g. by developing hypotheses of association or dependence with ex-post variables. As for the end users, leading indicators might allow a review of priorities and better interaction for bridging gaps in municipal equipment and/or guidelines. Both implications reinforce the core idea that policy-making necessarily needs to interconnect theory and practice. The pilot study, developed with hierarchies and relative positions as a basis, allows dissemination and use even in environments with less training in quantitative methods.

Further research based on this study may, e.g. (i) adopt a recombination of variables in the survey conducted by the IBGE, in order to ensure more reliable constructs; (ii) organize panels with information from other survey years already available, in order to outline progress of local sustainable development; (iii) select new samples in conurbation regions by using the method proposed herein, comparing them; (iv) through qualitative approaches, strive to achieve better interpretations of the reasons and effects as for whether there are specific variables in local development; (v) characterize, measure, and construe associations and dependence relationships with traditional indicators that provide economic, social, and environmental findings.

A significant point to be further explored is related to the apparent lack of association between policies and equipment focused on education, culture, and sports, whose interconnected approach might result in better outcomes for these populations, particularly bearing in mind values related to sustainable development and quality of life. This may prove to be an axis of extreme relevance to the discussion of the Law of Educational Accountability that has been debated in the Brazilian Congress.

The main constraint on the findings of this study derives from the non-release of data from the field survey conducted by the IBGE in 2011 which could provide more recent evidence of a practical nature for the purpose of discussing the current status of the Baixada Flumi- 
nense, concerning regional sustainable development: this creates difficulties for longitudinal or panel studies. Another limitation of this model is the legal approach, adopted for exploratory reasoning, which may turn the choice of indicators more distant from the expectations of local players.

The applicability of the protocol adopted herein seems quite suitable to situations of conurbation regions, where a richer metropolis establishes dependence relationships with its satellite cities, a typical issue of developing countries, or having marked socioeconomic inequalities even in neighboring cities. Operationalization contradicts the general perception of missing data to make public policies. In fact, the latter demonstrate a lack of legitimate wish to consolidate and process data to investigate and understand the reality beyond the political expediency view. So, the existence of a minimum legal framework, based on facts and data, is crucial to provide the State with parameters so that public managers work over time.

The main requirement to reproduce this method is the existence of a systematic data collection concerning the legal framework, which precedes the delimitation of sustainable development. Creating a checklist of minimally needed aspects with regard to the sustainability paradigm may lead to greater and more rapid convergence at times of scarcity or unbalanced consumption of resources.

\section{References}

ALBUQUERQUE, Roberto C. O desenvolvimento social no Brasil. Rio de Janeiro: José Olympio, 2011. ALVES, José C. D. Dos barões ao extermínio: uma história da violência na Baixada Fluminense. Duque de Caxias: Sepe; APPH-Clio, 2003.

ARAÚJO, Wilson A. Desenvolvimento econômico e arranjo produtivo local, uma relação necessária. São Paulo: Opção, 2010.

ASHLEY, Patrícia A. (Org.). Ética e responsabilidade social nos negócios. São Paulo: Saraiva, 2002.

AVENA, Regina C. S. Gestão ambiental — infraestrutura de transportes — ênfase em rodovias (manual of the student). National Department of Transports' Infrastructure, Road Research Institute - IPR. Brasília: 2011. Available at: < http://ipr.dnit.gov.br/Cursos2011/cursoGAR/apostila_gestao_ambiental_rev1_set2011_IPR.pdf>. Accessed on: 19 Dec. 2012.

BAÍA, Paulo R. S. A tradição reconfigurada: mandonismo, municipalismo e poder local no município de Nilópolis e no bairro da Rocinha na região metropolitana do Rio de Janeiro. PhD Thesis — Department of Development, Society and Agriculture, Program of Pos-Graduation in Development, Agriculture and Society, Rio de Janeiro, 2006.

BALATON GROUP. Indicators for sustainable development: theory, method, applications. International Institute for Sustainable Development. Canada: Hartmut Bossel, 1999.

BARBIERI, José Carlos. Desenvolvimento e meio ambiente: as estratégias de mudanças da Agenda 21. Petrópolis: Vozes, 2009. 
BOISIER, Sergio. Centralización y descentralización territorial en el proceso decisorio del poder público. Santiago de Chile: Ilpes/Cepal, 1995. p. 47-48. (Documento CPRD-95).

BRASIL. Política e estrutura da Secretaria de Desenvolvimento Regional do Ministério da Integração Nacional. 2011. Available at: <www.mi.gov.br/web/quest/apresentacao-sdr>. Accessed on: 19 Dec. 2012.

BRASIL. Política Nacional de Desenvolvimento Regional (PNDR). Ministério da Integração Nacional. Available at <www.integracao.gov.br/politica-nacional-de-desenvolvimento-regional-pnd >. Accessed on: 19 Dec. 2012.

BUARQUE, Sérgio C. Construindo o desenvolvimento local sustentável: metodologia de planejamento. Rio de Janeiro: Garamond, 2002.

CAETANO, Viviane A.; SILVEIRA, Suely F. R.; DRUMOND, Alexandre M. Análise da estratégia de desenvolvimento regional sustentável sob a ótica do desenvolvimento local: estudo de caso do município de Ervália — MG. Revista de Gestão Social e Ambiental — RGSA, v. 6, n. 3, p. 15-28, set./ dez. 2012.

CAMARGO, Ana L. de B. Desenvolvimento sustentável, dimensões e desafios. Campinas: Papirus, 2001.

CAMBA-MENDEZ, Gonzalo; KAPETANIOS, George; WEALE, Martin R. The forecasting performance of the OECD composite leading indicators for France, Germany, Italy and the UK. National Institute of Economic and Social Research. Working paper. London, 1999.

COSTA, Heloísa S. M. Desenvolvimento urbano sustentável: uma contradição de termos? Revista Brasileira de Estudos Urbanos e Regionais, n. 2, p. 55-71, nov. 1999.

DUARTE, Cristiane. Uma análise de procedimentos de leitura baseada no paradigma indiciário. Master thesis - Universidade de Campinas, Campinas, 1998.

ETSY, Daniel C.; PORTER, Michael E. Ranking national environmental regulation and performance: a leading indicator of future competitiveness. In: WORLD ECONOMIC FORUM. The Global Competitiveness Report 2001-2002. Oxford: Oxford University Press, 2002. p. 78-101.

EVERITT, Brian S. Cluster analysis. London: Heinemann Books, 1974.

EVERITT, Brian S.; DUNN, Graham. Applied multivariate analysis. London: Edward Arnold, 1991.

FARIAS, Luís O. Diagnóstico das condições socioeconômicas e da gestão pública dos municípios da Baixada Fluminense. Ministry of Social Works and Hunger Combat. Secretariat of Information Evaluation and Management. Brasília: 2005.

FERREIRA, Aracéli C. S. Contabilidade ambiental: uma informação para o desenvolvimento sustentável. São Paulo: Atlas, 2003.

FOGLIATTI, Maria Cristina et al. Sistema de gestão ambiental para empresas. Rio de Janeiro: Interciência, 2011.

FRANÇA FILHO, Genauto C. A via sustentável-solidária no desenvolvimento local. Revista Organizações \& Sociedade, v. 15, n. 45, p. 219-232, abr./jun. 2008. 
GINZBURG, Carlo. Sinais: raízes de um paradigma indiciário. In: GINZBURG, Carlo. Mitos, emblemas, sinais: morfologia e história. São Paulo: Companhia das Letras, 1989. p. 143-180.

GODET, Michel L. Introduction to la prospective: seven key ideas and one scenario method. Futures, Amsterdam, v. 18, n. 2, p. 134-157, apr. 1986.

GODET, Michel L. Manual de prospectiva estratégica: da antecipação à acção. Lisboa: Dom Quixote, 1993.

GUIVANT, Júlia S. Sustentabilidade e métodos participativos: os riscos dos pressupostos realistas. Working paper. World Congress of International Sociological Association. Brisbane, 2002.

HAIR, Joseph F. Jr. et al. Multivariate data analisys. London: Prentice Hall, 1998.

HASENCLEVER, Lia; FAURE, Yves. Caleidoscópio do desenvolvimento local no Brasil. Rio de Janeiro: E-papers, 2007.

HASENCLEVER, Lia; FAURE, Yves. Desenvolvimento local no estado do Rio de Janeiro. Rio de Janeiro: E-papers, 2005.

HOSSEINI, Hamideh M. Causality between pillars of sustainable development: Global stylized facts or regional phenomena? Ecological Indicators, v. 14, n. 1, p. 197-201, mar. 2012.

IBGE. Instituto Brasileiro de Geografia e Estatística. Indicadores de desenvolvimento sustentável: Brasil 2002/IBGE. Geosciences' Directory. Rio de Janeiro: IBGE, 2002.

IBGE. Instituto Brasileiro de Geografia e Estatística. Perfil dos municípios brasileiros: 2009. Available at: <www.ibge.gov.br/home/estatistica/economia/perfilmunic/2009/default.shtm>. Accessed on: 19 Dec. 2012.

JHA, Raghbendra; MURTHY, Bhanu K. V. Critique of the environmental sustainability index (april 2003). Australian National University Division of Economics Working Paper. Australian National University Division of Economics. Working Paper. Available at: < http://ideas.repec.org/p/pas/ papers/2003-08.html>. Accessed on: 19 Dec. 2012.

MANSELL, Robin; WEHN, Uta. Knowledge societies: information technology for sustainable development. United Nations Commission on Science and Technology for Development. New York: Oxford University Press, 1998.

MARCIAL, Elaine; GRUMBACH, Raul. Cenários prospectivos: como construir um futuro melhor. Rio de Janeiro: FGV, 2002.

MELLO, Claiton; STREIT, Jorge; ROVAI, Renato. Geração de trabalho e renda. Economia Solidária e desenvolvimento local: a contribuição da Fundação Banco do Brasil. São Paulo: Publisher Brasil, 2006.

MUNDA, Giuseppe; NARDO, Michela. Constructing consistent composite indicators: the issue of weigths. European Comission. Institute for the protection and security of the citizen. Luxemburgo, 2005.

OECD. Towards sustainable development: environmental indicators. Paris: OECD Publications, 1998. 
PEREIRA, Carlos Alberto M.; HERSCHMANN, Micael. Comunicação e novas estratégias organizacionais na era da informação e do conhecimento. Comunicação \& Sociedade, São Bernardo do Campo, v. 24, n. 38, p. 27-42, 2. sem. 2002.

PEREIRA, Carlos Alberto M.; HERSCHMANN, Micael. Metodologia e ações estratégicas no campo da comunicação e da cultura visando desenvolvimento local sustentável. Revista Brasileira de Comunicação Organizacional e Relações Públicas, v. 2, n. 3, p. 11-27, 2. sem. 2005.

RAVALLION, Martin. Mashup indices of development. Policy Research working Paper 5432. The World Bank Development Research Group. Washington: 2010.

RICHTER, Marcos G.; PESSOLANO, Juliana; REIS, Ayrton R. Pesquisa-ação e paradigma indiciário: construindo aproximações. Working paper. Available at: <www.ufsm.br/lec/01_02/MarcosJulianaAyrtonL.htm>. Accessed on: 8 Feb. 2012.

RIVERO, Oswaldo. O mito do desenvolvimento: os países inviáveis no século XXI. Petrópolis: Vozes, 2002.

RODRIGUES, Adriano O. De Maxambomba a Nova Iguaçu (1833-90's): economia e território em processo. Master dissertation - Program of Pos-Graduation in Urban and Regional Planning, Federal University of Rio de January, Rio de Janeiro, 2006.

ROESCH, Sylvia; FISCHER, Tânia; MELO, Vanessa P. Gestão social para o desenvolvimento: casos de ensino. Cadernos Gestão Social. Salvador: Ciags/UFBA, 2004.

SACHS, Ignacy. Desenvolvimento includente, sustentável. Rio de Janeiro: Garamond, 2004.

SANTOS, Milton. A natureza do espaço. São Paulo: Edusp, 2006.

SANTOS, Milton. Da totalidade ao lugar. São Paulo: Edusp, 2005.

SANTOS, Milton. Por uma geografia nova: da crítica da geografia a uma geografia crítica. São Paulo: Edusp, 2002.

SCOTTO, Gabriela; CARVALHO, Isabel C. M.; GUIMARÃES, Leandro B. Desenvolvimento sustentável. Petrópolis: Vozes, 2007.

SILVA, Ana C. F. R. Vozes da Baixada: um estudo sobre rádio comunitária em Queimados e São João de Meriti. Master dissertation - Program of Pos-graduation in Sociology, PUC-Rio, Rio de Janeiro, 2007.

SINAY, Maria C. F. et al. Sistema de gestão ambiental para empresas. Rio de Janeiro: Interciência, 2011. SINGH, Rajesh K. et al. An overview of sustainability assessment methodologies. Ecological Indicators, v. 15, p. 281-299, 2012.

TEIXEIRA, João P. B. Implementação de um sistema de gestão ambiental à luz da produção limpa: o caso da HJ Bahia. Monography — Escola Politécnica, Universidade Federal da Bahia, Salvador, 2006. VEIGA, José E. Desenvolvimento sustentável, um desafio do século XXI. Rio de Janeiro: Garamond, 2008. VIEIRA, Eurípides F.; VIEIRA, Marcelo M. F. Espaços econômicos: geoestratégia, poder e gestão do território. Porto Alegre: Sagra Luzzatto, 2003. 
WORLD BANK. Relatório sobre o desenvolvimento mundial 2010. Available at: <https://openknowledge.worldbank.org/bitstream/handle/10986/4387/WDR\%202010_Overview_P.pdf?sequence $=43>$. Accessed on: 19 Dec. 2012.

WORLD COMMISSION ON ENVIRONMENT AND DEVELOPMENT. Nosso futuro comum. Rio de Janeiro: FGV, 1991.

WORLD ECONOMIC FORUM. Pilot environmental performance index. Global leaders of tomorrow environment task force. Annual Meeting, 2002. Available at: <www.ciesin.columbia.edu/indicators/ ESI>. Accessed at: 19 Dec. 2012.

ZAPATA, Tania et al. Desenvolvimento local: estratégias e fundamentos metodológicos. Rio de Janeiro: Rits, 2001.

José Francisco de Carvalho Rezende has a doctorate degree (DSc) in the field of Business Administration Sciences from the Instituto Coppead/UFRJ, is associate professor at the Programa de Pós-Graduação em Administração da Unigranrio and coordinates the Mais Baixada project. E-mail: rezende.jose@unigranrio.edu.br.

Maria Cristina Fogliatti de Sinay has a doctorate degree (PhD) in the field of Applied Mathematics from the City University of New York and is associate professor at the Programa de Pós-Graduação em Administração da Unigranrio. E-mail: CristinaSinay@gmail.com.

\section{Appendix 1}

\section{Constructs and variables}

\begin{tabular}{|ll|}
\hline \multicolumn{1}{|c|}{ Constructs } & Binary variables \\
Municipal Planning (PLA) & Existence of: urban development council; specific legislation on the field of social \\
& interest; specific legislation on zone and/or area of special interest; land sub- \\
& division law; zoning law; building construction code; rules set forth in technical \\
& standards on accessibility; behavior code; master plan; master plan for building \\
& construction. \\
& Existence of: real estate registry; ISS service tax registry; control for the \\
& establishment of enterprises; industrial district regulated by a specific state \\
Local Management and ICT (MAN) & or municipal law; job and income generation programs or actions; first job \\
& support policy for young people and adolescents; internet use (website, portal, \\
& homepage, email); town hall computer network; town hall computers with \\
& internet access; digital inclusion policy or plan. \\
& Existence of: regulation and enhancement of teaching careers; projects focused \\
& on education for young people and adults; institution offering vocational \\
& training courses; education council; cultural heritage legislation; culture council; \\
Education, Culture, and Sports (ECS) & institutions of higher education; basic law on sports; sports council; town hall \\
& sports calendar. \\
\hline
\end{tabular}




\begin{tabular}{|c|c|}
\hline Constructs & Binary variables \\
\hline Housing and Transportation (H\&T) & $\begin{array}{l}\text { Existence of: housing plan; housing fund; unified housing budget management; } \\
\text { registry or survey of families for housing programs; preferential and/or priority } \\
\text { criteria for assisting identified people; specific land ownership legalization } \\
\text { plan and/or program; transportation council; collective transportation by city } \\
\text { bus services; accessibility criteria and standards for concessions, permits, or } \\
\text { authorizations into consideration; public transportation by inter-municipal bus } \\
\text { services. }\end{array}$ \\
\hline Healthcare and Social Welfare (H\&W) & $\begin{array}{l}\text { Existence of: health council; health fund; plan; maternity clinic; maternity } \\
\text { clinic with birth registry office; emergency units; laboratory for clinical analysis; } \\
\text { government-subsidized pharmacy; community healthcare agent program; family } \\
\text { health program. }\end{array}$ \\
\hline Safety and Access to Justice (S\&J) & $\begin{array}{l}\text { Existence of: public security plan; civil police station; medical examiner's } \\
\text { office; environmental protection station; official access to violent crime records } \\
\text { produced by the State; fire department; municipal guards; district courts; } \\
\text { specialized agrarian dispute settlement unit; legal assistance. }\end{array}$ \\
\hline Human Rights and Diversity (HRD) & $\begin{array}{l}\text { Existence of: policy plan for women; reference centers for battered women; tool } \\
\text { to receive denounces of non-compliance with human rights; policy or actions } \\
\text { against forced labor; actions for homeless people; policy, program, or action to } \\
\text { resocialize former prisoners; policy or program for the elderly; policy for children } \\
\text { and adolescents; prison home for adolescents in conflict with the law; child } \\
\text { protection council. }\end{array}$ \\
\hline Environment (ENV) & $\begin{array}{l}\text { Existence of: environment council; environment fund; legislation to issue } \\
\text { environmental licenses and activities with local impacts; local agenda } 21 \\
\text { preparation process; environmental legislation; hydrographic basin committee; } \\
\text { intermunicipal public partnership agreement; public partnership agreement with } \\
\text { the State; public partnership agreement with the federal government; public } \\
\text { partnership agreement with the private sector. }\end{array}$ \\
\hline
\end{tabular}

